\title{
VOLATILE SOLID KINETIC DEGRADATION OF EFB BIOWASTE COMPOSTING PROCESS
}

\author{
ALKARIMIAH, R. ${ }^{{ }^{*}}-$ SUJA $^{\prime}$, F. $^{2}$

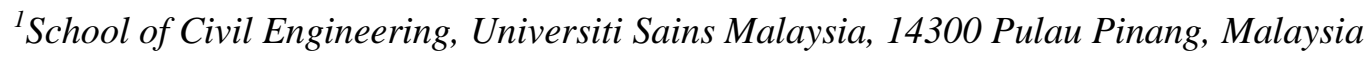 \\ ${ }^{2}$ Faculty of Engineering and Built Environment, Universiti Kebangsaan Malaysia, 43600 Bangi, \\ Selangor, Malaysia \\ (phone: +60-38-911-8364/8911/8354; fax: +60-38-911-8355) \\ *Corresponding author \\ e-mail: cerosnani@usm.my; phone: +60-45-996-264; fax:+60-45-996-906 \\ (Received 22 $2^{\text {nd }}$ Apr 2019; accepted $11^{\text {th }}$ Jul 2019)
}

\begin{abstract}
Volatile Solid (VS) parameters are used to study kinetic changes in compost materials. The Michaelis-Menten model is used in determining the volatile kinetics of the process. The composting materials used only are shredded empty fruit bunches (EFB) and palm oil mill effluent (POME) sludges obtained from the palm oil mill plantation. All the composting processes carried out in this study were performed in the rotary drum reactor. This experiment is conducted with 4 different runs. Run A used 10 $\mathrm{kg}$ EFB ratio: $1 \mathrm{~kg}$ sludge: $5 \mathrm{~kg}$ recycle compost, Run B with $5 \mathrm{~kg}$ EFB: $0.5 \mathrm{~kg}$ sludge: $2.5 \mathrm{~kg}$ recycle compost and Run $\mathrm{C}$ at $5 \mathrm{~kg}$ ratio EFB: $2.0 \mathrm{~kg}$ sludge: $0.5 \mathrm{~kg}$ recycle compost. The highest temperature achieved is $55^{\circ} \mathrm{C}$ (Run A), $43 \mathrm{C}$ (Run B) and $53.3^{\circ} \mathrm{C}$ (Run C). For the final $\mathrm{C} / \mathrm{N}$ ratios for Run A, B, C and $\mathrm{D}$ are 20.61, 17.54, 13.06 and 14.51 respectively. Based on the results of the four Runs that have been done, it is found that the kinetic change in Run has the best mathematical expression $y=103.31^{-0.015 x}$ with $\mathrm{R}$-square value of 0.9097 and derived $\mathrm{K}_{1}$ value of this study is 106.0117 and $\mathrm{K}_{2}$ is 0.012 .
\end{abstract}

Keywords: Michaelis-Menten model, shredded EFB, POME sludge, rotary drum reactor

\section{Introduction}

Composting is a biochemical degradation process of organic substances that are converted into a cleaner material and a more stable humus. The main factors in controlling the composting process include the parameters of the environment such as temperature, moisture content, $\mathrm{pH}$ and ventilation as well as natural parameters of the substrate material such as $\mathrm{C} / \mathrm{N}$ ratio, particle size and nutrient content. In determining the degradation and creating useful measurements in the loss of organic matter during the composting process, it is necessary to determine the kinetic process using the data obtained from experimental studies under controlled conditions. According to Levenspiel (1999), kinetics is generally a study of the rate or speed of a reaction. Substrate degradation models play a key role in the mathematical modelling of temperature, moisture and oxygen profiles in the composting process. In relation to temperature prediction, mathematical models have been shown to be mainly successful in simulating the basic shape of composting temperature profiles However, less precise in forecasting peak temperature, and the time required to reach it (Mason, 2009).

Most kinetic parameters are usually used to describe the nature of maturity of compost materials. The nature of maturity of composting materials that is often used is the properties of physico-chemical changes such as $\mathrm{C} / \mathrm{N}$ ratio, ash and cation capacity change (Planas and Pelaez, 2001). However, there are also studies using enzyme activity measurement as an indicator of composting activity (Pelaez et al., 2004). In general, studies on kinetic changes in composting process are important to obtain a 
chemical change pattern on the nature of the reaction system, and it is also an important basis for the theory in the combustion and dissolution process which then provides a method for studies involving heat conversion and mass. Knowledge of kinetic reaction changes will also help in the design of a composting system (Manu et al., 2016).

Researchers have studied the determination of decomposition in the composting process. Various parameters have been studied such as the use of oxygen content (Pressel and Bidling Maier, 1981), carbon mineralization rates (Bernal et al., 1998), carbon fractions (Whang and Meenaghan, 1980; Gilmour et al., 1996), biodegradation of lignocellulose (Vikman et al., 2002), biodegradation of polyatic acid (PLA) (Stloukal et al., 2015), biodegradable volatile solid degradation (Mason, 2008; Zhang et al., 2010), organic matter degradation (Kulikowska, 2016; Ge et al., 2015; Manu et al., 2016; Petric et al., 2012; Bustamante et al., 2008), thermal decomposition reaction (Giwa et al., 2018). Tiqua et al. (1996) have studied the changes in microbial characteristics including heterotrophic aerobic population, oxygen consumption rate, dehrogenic activity and $\mathrm{C} / \mathrm{N}$ microbial mass during pine-stool composting process and wood dust straw. Yamada and Kawase (2006) also reviewed kinetic analysis for microbiological and oxygen use reactions for activated sludge aerobic composting process. In their study, microbiological responses are represented by the Monod equation.

Whang and Meenaghan (1980), Seng (1999) and Tweib et al. (2014) have studied the characteristics of the kinetic composting process. They have measured carbon fractions by using CHN analyzer tools as early as 6-8 days of composting process. They have discovered the characteristics of the composting process using the Michaelis-Menten model. From the study, they have concluded that the constant Michaelis-Menten, $\mathrm{K}_{1}$ is a constant representing the description of a system used. This study aims to evaluate the rate of kinetic change of volatile substance in the rotary drum reactor. The analysis steps developed in this study can be used to obtain $K_{1}$ and $K_{2}$ values in a step to increase the composting scale to pilot scale by using Michaelis-Menten model.

\section{Methodology}

\section{Raw material and reactor design}

The main raw materials used in this study are palm oil mill effluent (POME) sludge and empty fruit bunches (EFB). Shredded fresh empty fruit bunches (EFB) used for compost materials were obtained from Sri Ulu Langat Palm Oil Processing Factory, Dengkil, Selangor, Malaysia. Meanwhile, POME sludge for this study is gathered from conventional aerobic pond treatment from same factory. Recycle compost also used in the mixing of fresh sample for this experiment. The recycle compost is obtained from EFB and POME composting process that is more than 1 year old from previous experiments. Figures 1 and 2 show the shredded EFB and POME sludge from conventional aerobic pond treatment gathered for this study. While, Table 1 shows the chemical and physical characteristics of the raw materials and recycle compost that used in this experiment.

Rotary drum reactor system that used in this study facilitated with 3 phase motors. The rotary drum reactor is made from stainless steel measuring $3 \mathrm{~m}$ long with a diameter of $0.6 \mathrm{~m}$ and an initial active volume of $0.4 \mathrm{~m}^{3}$. The rotary drum reactor works with the support of a 3-phase motor system with a maximum 2 rotation per minute. There are 8 inner blades with length of $5 \mathrm{~cm}$ each in order to enhance the mixing in the 
reactor. Mixing of palm oil mill effluents (POME) and empty fruit bunches (EFB) insert through the feeding part. Figure 3 shows the schematic diagram of the rotary drum reactor used in this study.

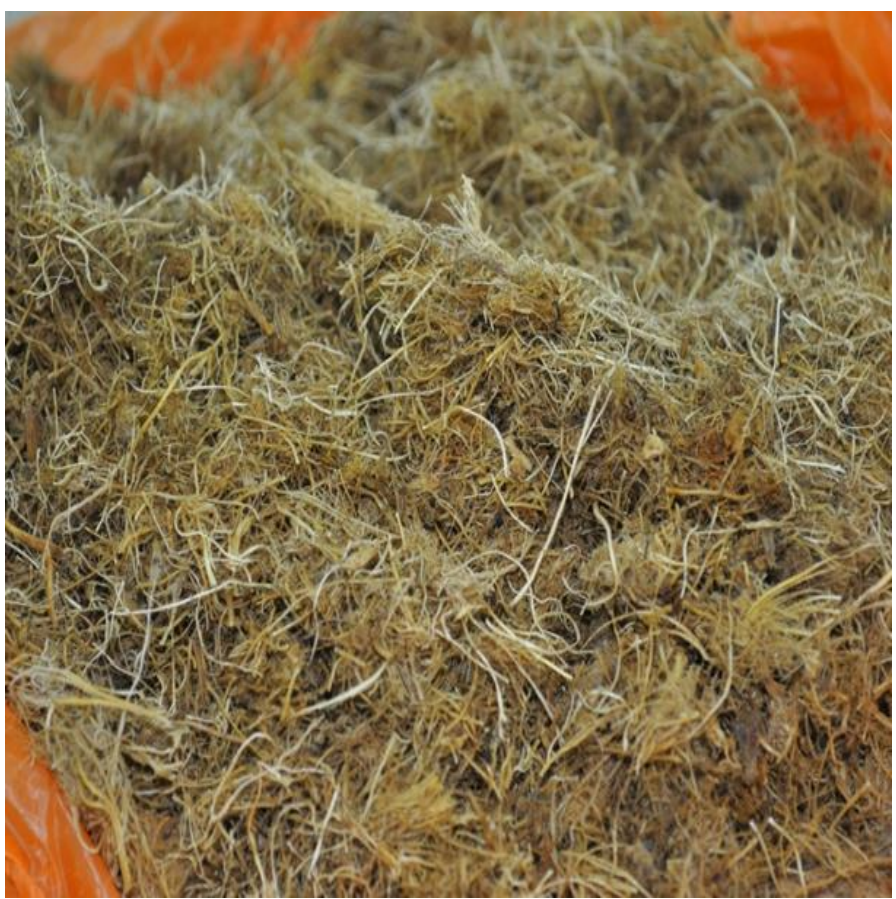

Figure 1. Shredded fresh empty fruit bunches (EFB)

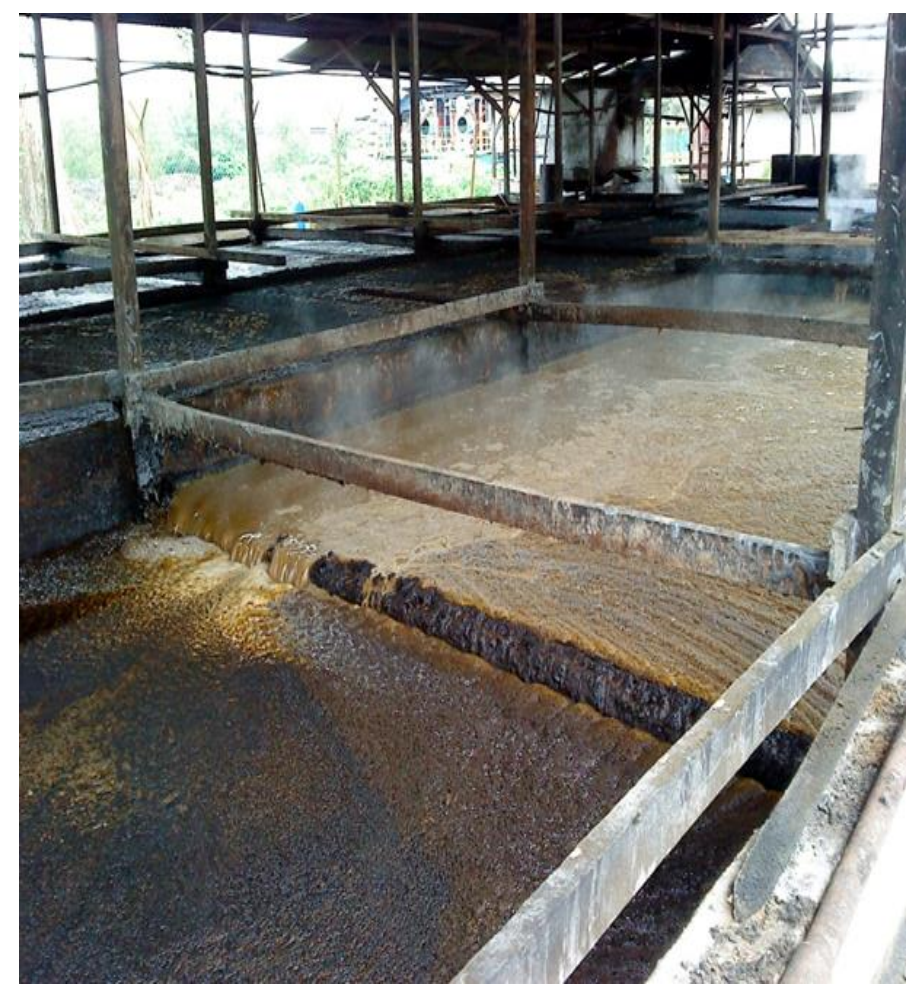

Figure 2. Palm oil mill effluent (POME) sludge gathered from conventional aerobic pond treatment 
Table 1. The chemical and physical properties of the raw materials

\begin{tabular}{c|c|c|c}
\hline Parameter & $\begin{array}{c}\text { Fresh empty fruit } \\
\text { bunches (EFB) }\end{array}$ & $\begin{array}{c}\text { Aerobic palm oil mill } \\
\text { effluent (POME) sludge }\end{array}$ & $\begin{array}{c}\text { Recycle } \\
\text { compost }\end{array}$ \\
\hline Moisture Content, \% & $24 \pm 5.8$ & $94 \pm 3.3$ & $80 \pm 0.5$ \\
\hline $\mathrm{pH}$ & $6.7 \pm 0.2$ & $7.5 \pm 0.5$ & $7.59 \pm 0.3$ \\
\hline $\begin{array}{c}\text { Total organic carbon (TOC), } \\
\% \text { dry weight }\end{array}$ & $53 \pm 1.5$ & $19.0 \pm 1.6$ & $12.43 \pm 1.5$ \\
\hline $\begin{array}{c}\text { Total Kjedahl nitrogen } \\
(\mathrm{TKN}) \% \text { dry weight }\end{array}$ & $0.9 \pm 0.1$ & $2.3 \pm 0.2$ & $1.21 \pm 0.9$ \\
\hline C/N & 58.9 & 8.3 & 10.3 \\
\hline
\end{tabular}

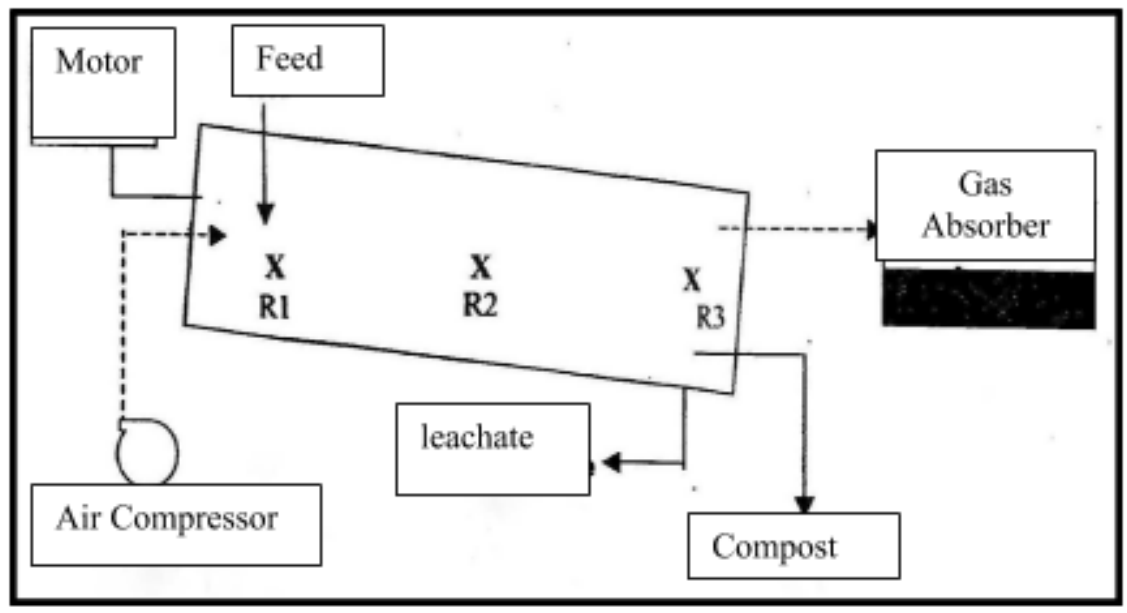

Figure 3. Schematic diagram of rotary drum reactor

\section{Temperature profile observation}

The temperature of the compost in the reactor is obtained by using the thermometer probe (Digital Thermometer, Thermocouple Thermometer Type K, Nicety ${ }^{\circledR}$ DT804, US). Figure 4 shows the digital thermometer used to indicate the temperature reading throughout the composting process. The length of this probe thermometer is $1 \mathrm{~m}$. Therefore, temperature readings on composting materials within the reactor can be taken up to 1 meter from the input section (at point R2 referring to Fig. 3). The temperature reading of this study is taken twice daily, i.e. in the morning and in the evening. The probe thermometer embedded into the compost heap is left for 5-10 min until the reading on the digital display of the thermometer starts stable.

\section{Preparation of compost mixture}

In this experiment, fresh and shredded EFB has been mixed with POME sludge. On average, the length of EFB fiber size taken fresh from the plant used in this phase is within 3-13 cm. In general, smaller particles of organic matter particles will provide sufficient surface area for bacterial and microorganisms reactions. EFB mixtures and POME sludge are mixed manually outside the reactor before being added into a rotary drum. For Run A, as much as $10 \mathrm{~kg}$ EFB, $5 \mathrm{~kg}$ of recycle compost and $2 \mathrm{~kg}$ of POME sludge is manually mixed before being put into a rotary drum reactor every day. For Run B $5 \mathrm{~kg}$ EFB, $2.5 \mathrm{~kg}$ of recycle compost and $2 \mathrm{~kg}$ of POME sludge added daily into 
the reactor. Meanwhile for Run C, $5 \mathrm{~kg}$ of EFB, $0.5 \mathrm{~kg}$ of recycle compost and $2.0 \mathrm{~kg}$ of POME sludge added daily. For this experiment runs, only one-time replicate has been carried out of each mixture. Table 2 shows the mixing ratio of this experimental runs.

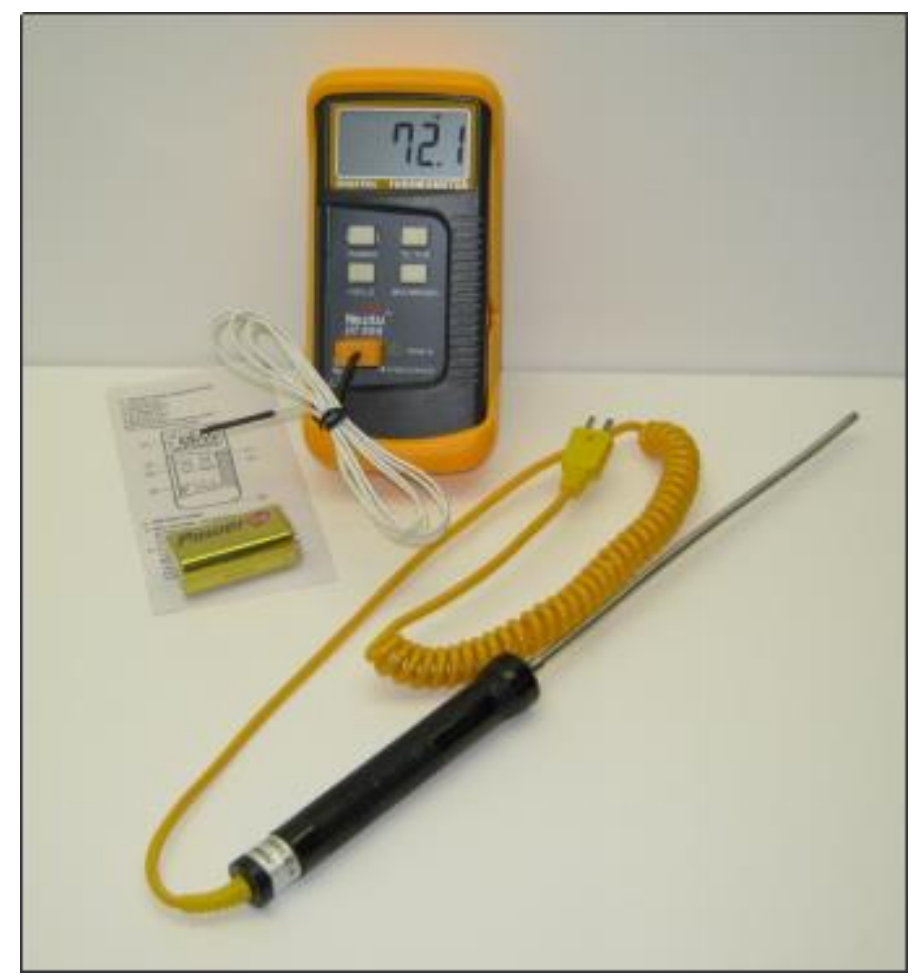

Figure 4. Thermometer digital and thermocouple Type $K$ (Nicety ${ }^{\circledR}$ DT804)

The process of adding compost materials of each Runs into a rotary drum is done on daily basis until the content of the drum reactor reaches $90 \%$ full. In total, $150 \mathrm{~kg}$ of EFB fiber (a mixture of fresh EFB fiber and recycle compost) and $30 \mathrm{~kg}$ of POME sludge have been used for each Runs in this study. From the observations on Run A, the compost product reached at the outlet section on the day $11^{\text {th }}$. Meanwhile, for Run B and Run $\mathrm{C}$ the compost product resulted at the outlet section on the day $16^{\text {th }}$.

The compost products that comes out at the outlet section will then be restored into the rotary drum reactor in the feed section until the composting process is completed. For sampling purposes for $\mathrm{pH}$ parameters, moisture content, fiber length, nutrient content and $\mathrm{C} / \mathrm{N}$ ratio, $200 \mathrm{~g}$ of compost was gathered. The sampling process for the above parameters is taken every 3 days. For the temperature parameter, the reading is taken every day in the morning and in the evening. All the compost samples taken were then stored in the frozen room at $4{ }^{\circ} \mathrm{C}$ before being analyzed.

Table 2. Weight and mixing ratio between empty fruit bunches (EFB), palm oil mill effluent (POME) sludge and recycle compost on each experimental runs

\begin{tabular}{c|c|c|c|c|c}
\hline Run & $\begin{array}{c}\text { EFB } \\
(\mathbf{k g})\end{array}$ & $\begin{array}{c}\text { POME sludge } \\
(\mathbf{k g})\end{array}$ & $\begin{array}{c}\text { Recycle compost } \\
(\mathbf{k g})\end{array}$ & $\begin{array}{c}\text { Mixing } \\
\text { ratio }\end{array}$ & $\begin{array}{c}\text { Operational period } \\
(\text { days })\end{array}$ \\
\hline A & 10 & 1 & 5 & $10: 1: 5$ & 43 \\
B & 5 & 0.5 & 2.5 & $5: 0.5: 2.5$ & 23 \\
C & 5 & 2.0 & 0.5 & $5: 2: 0.5$ & 29 \\
\hline
\end{tabular}




\section{Volatile solid and carbon content}

To analyze the carbon content, the ash method was used is. Sub-samples of dried compost from moisture content analysis were then burned in the furnace for 4 hours at $550^{\circ} \mathrm{C}$. Volatile solid computations are shown in Equation 1 below:

$$
\% \text { Volatile Solid }=\frac{X 1-X 2}{X 1-M} \times 100
$$

where $\mathrm{X} 1=$ Initial sample weight and crucible before furnaced, $\mathrm{X} 2=$ Final sample weight and crucible after furnaced, $\mathrm{M}=$ Crucible weight.

Organic matter is estimated to be equivalent to volatile matter/solid (Hoyos et al., 2002). Therefore, the amount of organic carbon can be determined using the formula as shown in Equations 2 and 3 according to Hoyos et al. (2002).

$$
\begin{gathered}
\text { \% Carbon } C=\frac{\% \text { Organic matter }}{1.8} \\
=\frac{\% \text { Volatile solid }}{1.8}
\end{gathered}
$$

whereby 1.8 is constant.

\section{Kinetic study}

The Michaelis Menten model is a widely used kinetic model in the study of biochemical enzyme reactions that estimate the formation of complex mixtures simultaneously under quasi-equilibrium conditions. Whang and Meenaghan (1980), Seng (1999) and Tweib et al. (2014) have adapted this model in their composting studies. Conceptual reaction mechanisms are interpreted by the following stoichiometric schemes, where the equation rates have been simplified and mathematically manipulated to achieve satisfactory results in the graphic attempts as shown in the following Equation 4. Figure 5 shows how the kinetic study was carried out using the Michaelis-Menten model in this study

$$
C+X \leftrightarrow C X \rightarrow X+P
$$

where $\mathrm{C}=$ Substrate, $\mathrm{X}=$ Free organism, $\mathrm{CX}=$ Activated substrate-organic complex, $\mathrm{P}=$ Product from endogenous reaction.

The second estimate made is an endogenous reaction is irreversible based on practical view. Mass stability equations for activated complex substrate microbes, CX can be described as Equation 5 below:

$$
\frac{D(C X)}{D_{t}}=k_{1}(C)(X)-\left(k_{-1}+k_{2}\right)(C X)
$$


where $\mathrm{K}_{1}=$ the reaction rate constant of the forward reaction by converting substrate $(\mathrm{C})$ and free organism $(\mathrm{X})$ to the active complex organism substrate $(\mathrm{CX}), \mathrm{k}_{-1}=$ the reaction rate constant of the inverse reaction by converting substrate $(\mathrm{C})$ and free organism $(\mathrm{X})$ to the active complex organism substrate $(\mathrm{CX}), \mathrm{k}_{2}=$ the reaction rate constant of the forward reaction by converting the complex organism substrate $(\mathrm{CX})$ to the free organism $(\mathrm{X})$ and the product $(\mathrm{P})$.

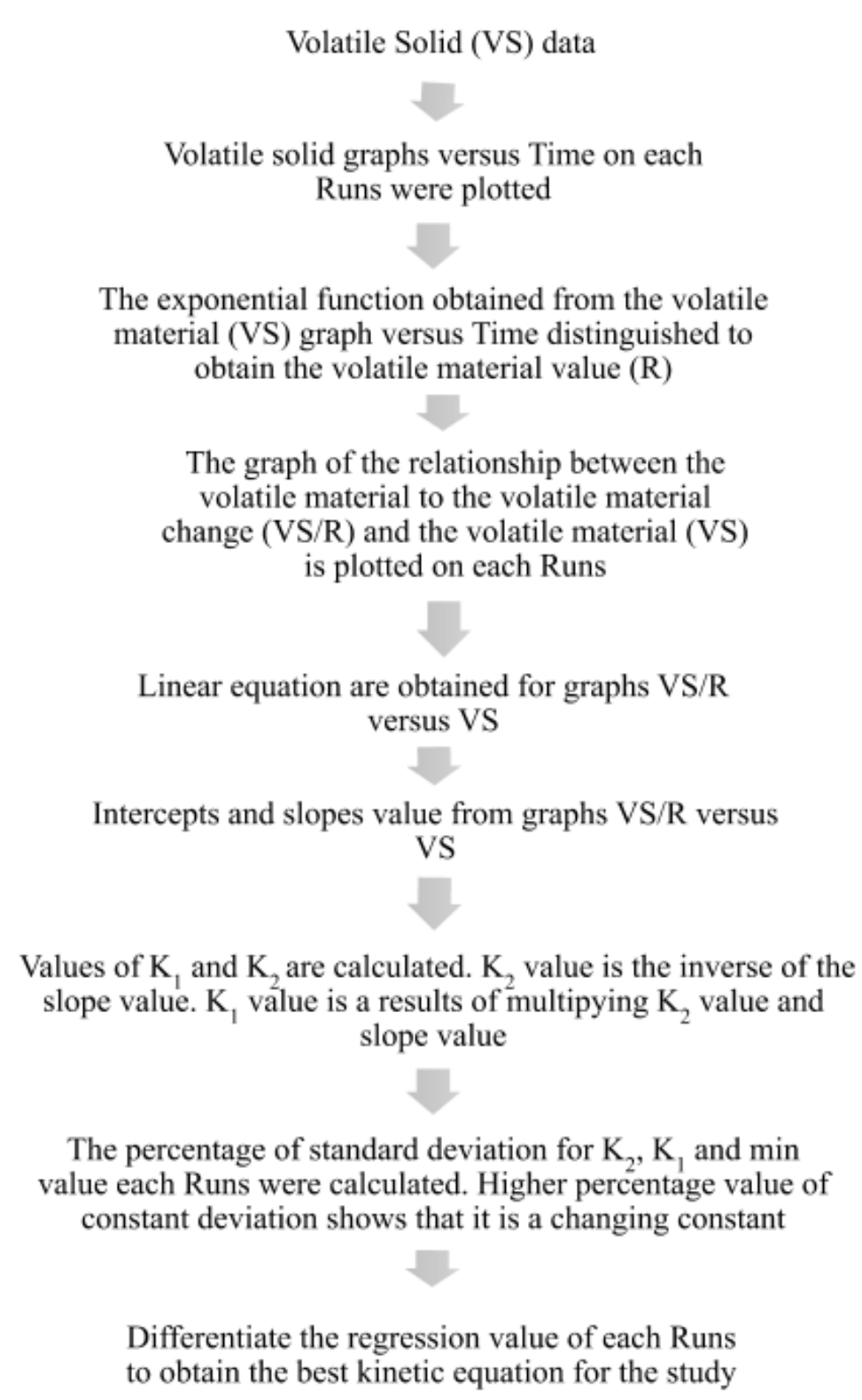

Figure 5. Michaelis-Menten model kinetic study procedure

The estimation for an indirect quasi-equilibrium state as Equation 6:

$$
\frac{D(C X)}{d t}=0
$$

Therefore, Equation 5 becomes Equation 7 as follows: 


$$
(C X)=\frac{(C)(X)}{K_{1}}
$$

where $\mathrm{k}_{1}$ is obtained from Equation 8,

$$
K_{1}=\frac{K-1+k_{2}}{k_{1}}
$$

Product production rate $(\mathrm{P})$ is equal to the substrate rate estimate. Therefore Equation 9 is,

$$
\frac{d(P)}{d t}=R=k_{2}(C X)
$$

where, $\mathrm{R}=$ substrate estimation rate.

In the meantime, the concentration of microorganisms, XT, can be expressed as Equation 10 as below:

$$
X_{t}=X+C X
$$

By completing the Equation 10 and replacing it in Equation 11:

$$
C X=\frac{(C)\left(X_{T}\right)}{K_{1}+C}
$$

From Equations 10 and 11, the R value is obtained by using Equation 12:

$$
R=\frac{K_{2}(C)}{K_{1}+(C)}
$$

Where the calculated value of $\mathrm{K}_{2}$ is obtained from Equation 13:

$$
K_{2}=k_{2}\left(X_{T}\right)
$$

Therefore, Equation 13 is the kinetic equation for the composting process.

\section{Results and discussion}

\section{Temperature profile}

Temperature gives a huge impact on microbiological processes. Important responses and other elements of composting processes are also affected by temperature changes. Time-temperature relationship affects the rate of decomposition of organic matter and therefore it is important to produce stable and mature compost products for application of plants. In this study, the temperature reading is taken before the compost material is added (morning time), and after the compost material is added (evening time) into the 
rotary drum reactor. The composting process of Run A is run for 43 days. The initial temperature of the Run A compost mixture is $31.8^{\circ} \mathrm{C}$.

At Run A, the highest temperature reached was $55^{\circ} \mathrm{C}$ on the 10 th day of composting process, after composting was added. Temperatures within the range $40-55^{\circ} \mathrm{C}$ remain for 24 days on the Run A composting process. On day 35 the temperature of the composting process began to show a decrease to the range of 32.1-38.1 C until the end of the composting process. The increase in temperature to the thermophilic phase between $50-70^{\circ} \mathrm{C}$ during composting is indispensable for the destruction of pathogens and parasites.

Meanwhile, the initial temperature of Run B composting material is $32^{\circ} \mathrm{C}$. The increase in temperature on Run B is seen evenly, i.e. from $32^{\circ} \mathrm{C}$ (initial temperature) to $39.9^{\circ} \mathrm{C}$ on day 3 . On day 4 , the temperature starts to reach $40^{\circ} \mathrm{C}$ range. On Run $\mathrm{B}$, compost temperature remains in the range $40-43^{\circ} \mathrm{C}$ (the highest temperature reached on the $11^{\text {th }}$ day). The final day of composting, the temperature value before the sample was entered and after the sample was entered has decreased to $37^{\circ} \mathrm{C}$ and $39.6 \mathrm{C}$ respectively. The compost temperature of this mixture is seen to not achieve optimum temperature of $45^{\circ} \mathrm{C}$. This may be due to a $5 \mathrm{~kg}$ mix EFB: $2.5 \mathrm{~kg}$ recycled compost: $1 \mathrm{~kg}$ of POME sludge is not an ideal mix for the optimal development of microbes in compost heap.

The initial temperature of compost material on Run $\mathrm{C}$ was $25.5^{\circ} \mathrm{C}$. The observed temperature increases gradually in this run. The temperature within the range $30^{\circ} \mathrm{C}$ lasts for 8 days at the beginning of the composting process. Starting from day 9, the temperature starts to raise into the range $40^{\circ} \mathrm{C}$ until day 22 . On day 23 , Run D composting temperature increases to $53.3^{\circ} \mathrm{C}$. Temperatures within the range of $50^{\circ} \mathrm{C}$ to $53^{\circ} \mathrm{C}$ are seen to last for only 4 days. On 27 th day the temperature began to decline again with the final temperature of $36.7^{\circ} \mathrm{C}$ before the addition of composting material and $45.8 \mathrm{C}$ after composting material was added.

From the three mixtures, the mesophilic phase begins in the first 3-8 days of the composting process. The abundance of organic substances at present has encouraged the activity of microorganisms and subsequently generating heat energy which causes temperature rise to occur. When temperatures rise above $45^{\circ} \mathrm{C}$, thermophilic microorganisms will dominate the compost mass. Figure 6 shows the temperature profile for Run A, B and C.

\section{Volatile solid degradation}

In this study, the degradation kinetics of the volatile material were used to study the kinetic changes of compost materials. The Michaelis-Menten model is used in determining the kinetic content of volatile composting samples. All the data from the experiments obtained are appropriate to the exponential function. Figures 7-9 show graphs of volatile material against time for each Run.

Table 3 shows the exponential function obtained from the experimental runs along with the regression factor for the volatile solids compost material against the time of the study conducted.

The exponential function obtained as described in the table above is then differentiate. The differential equations obtained from the above exponential function represent the volatile solid change $(\mathrm{R})$ in the compost material. The differential equation of the all Runs as shown in Equations 14-16 below. 


$$
\begin{aligned}
& \text { Run } A: R=\frac{d x}{d y}=0.674 x^{-1.007} \\
& \text { Run } B: R=\frac{d x}{d y}=1.5497 x^{-1.015} \\
& \text { Run } C: R=\frac{d x}{d y}=1.1859 x^{-1.012}
\end{aligned}
$$

Table 3. Exponential function and regression factor for volatile solid

\begin{tabular}{c|c|c}
\hline Run & Exponential function & Regression factor \\
\hline A & $\mathrm{Y}=96.366^{(-0.007 \mathrm{x})}$ & 0.724 \\
B & $\mathrm{Y}=103.31^{(-0.015 \mathrm{x})}$ & 0.909 \\
C & $\mathrm{Y}=98.828^{(-0.012 \mathrm{x})}$ & 0.785 \\
\hline
\end{tabular}

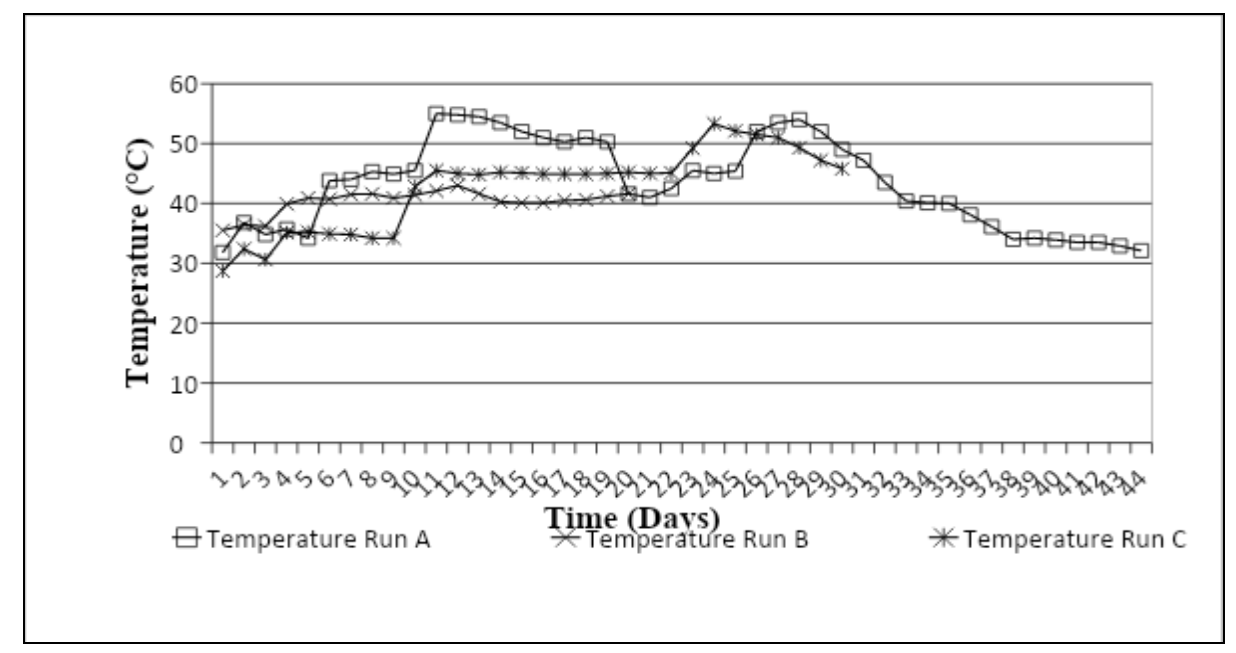

Figure 6. Temperature profile for Run B to Run C

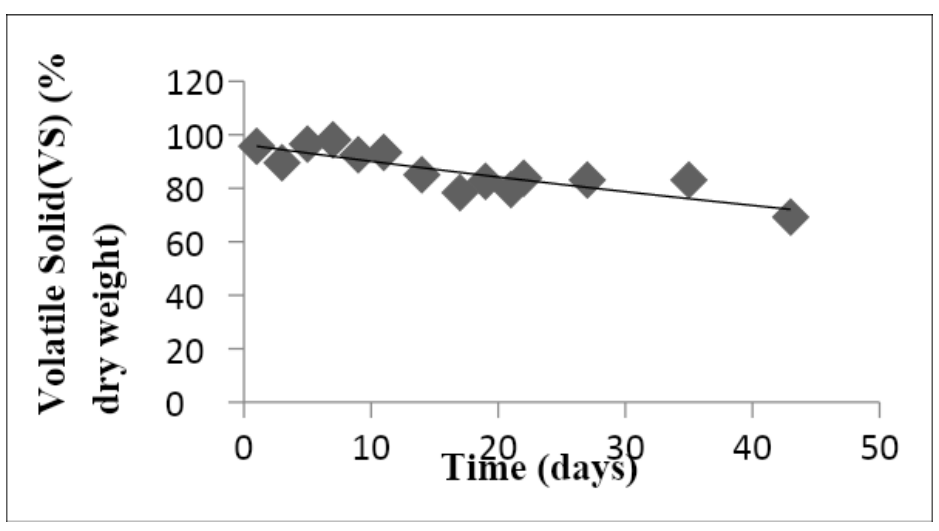

Figure 7. Volatile solid changes on Run A 


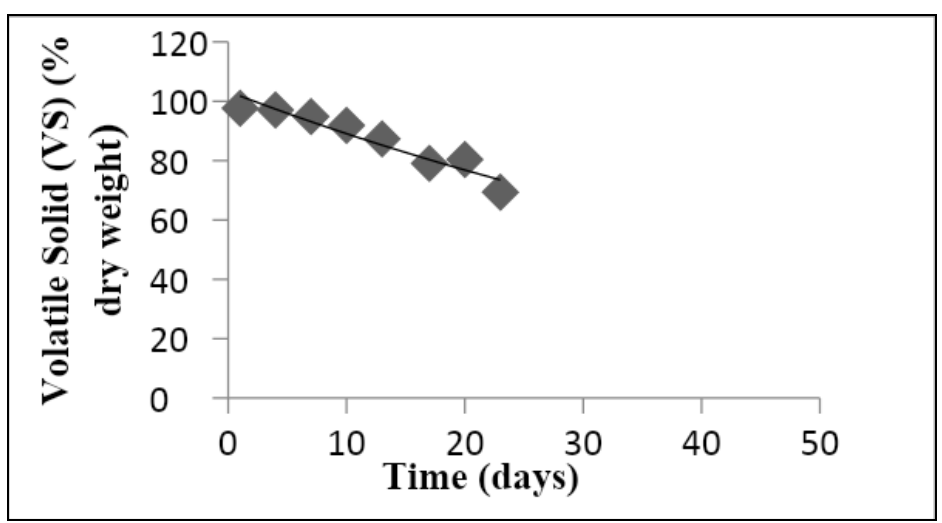

Figure 8. Volatile solid changes on Run B

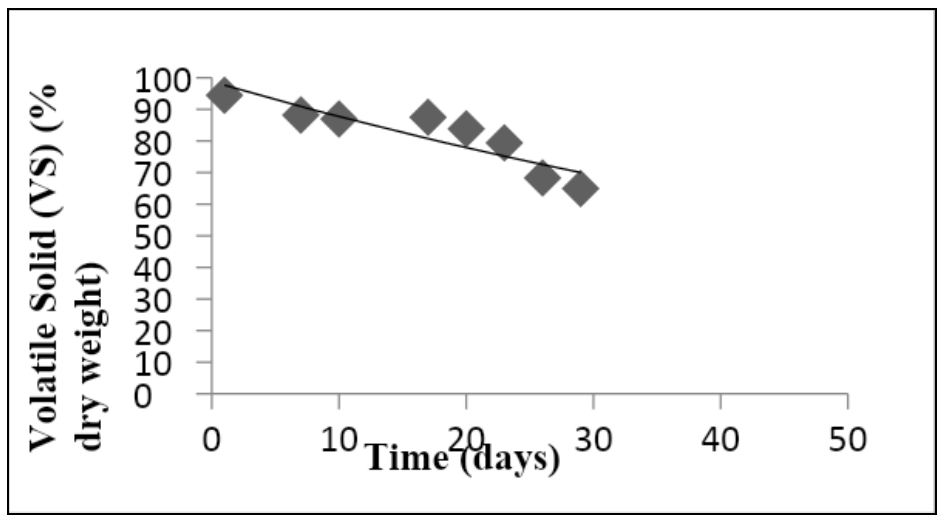

Figure 9. Volatile solid changes on Run C

From the volatile solid value (VS) and the volatile solid change value (R), the relationship between the volatile solid to the volatile solid change (VS/R) and volatile solid (VS) can be correlated graphically. The relationship between volatile solid to volatile solid change (VS/R) and volatile solid (VS) is most suitable for linear equations. The VS/R graph against VS on each Runs is shown in Figures 10-12.

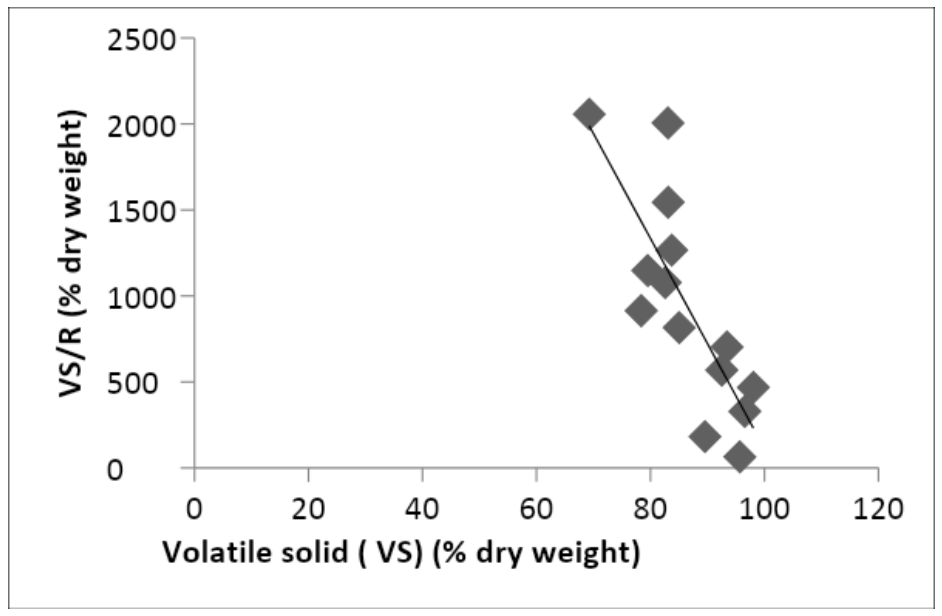

Figure 10. VS/R against VS for Run A 


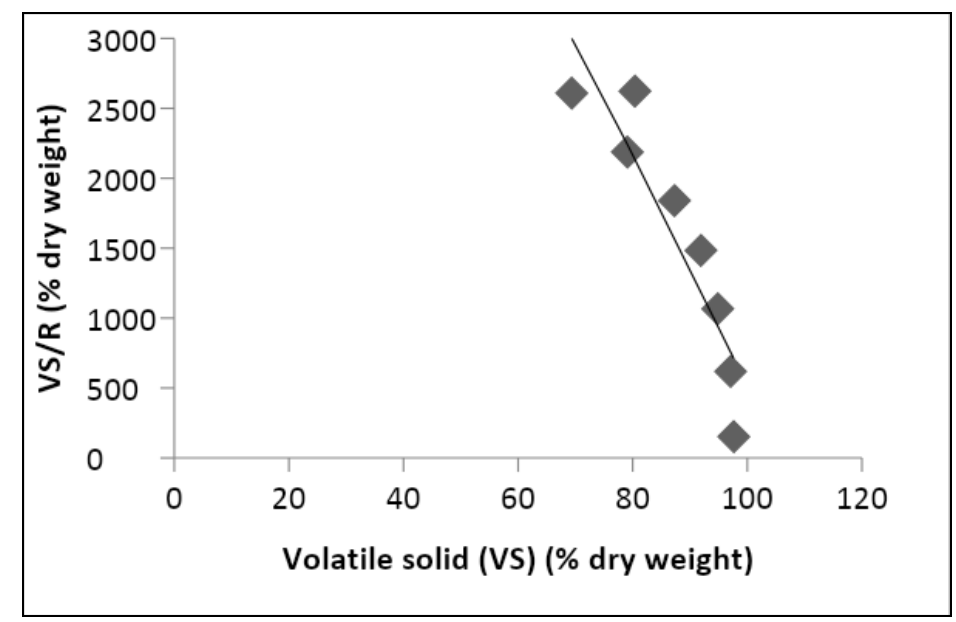

Figure 11. VS/R against VS for Run B

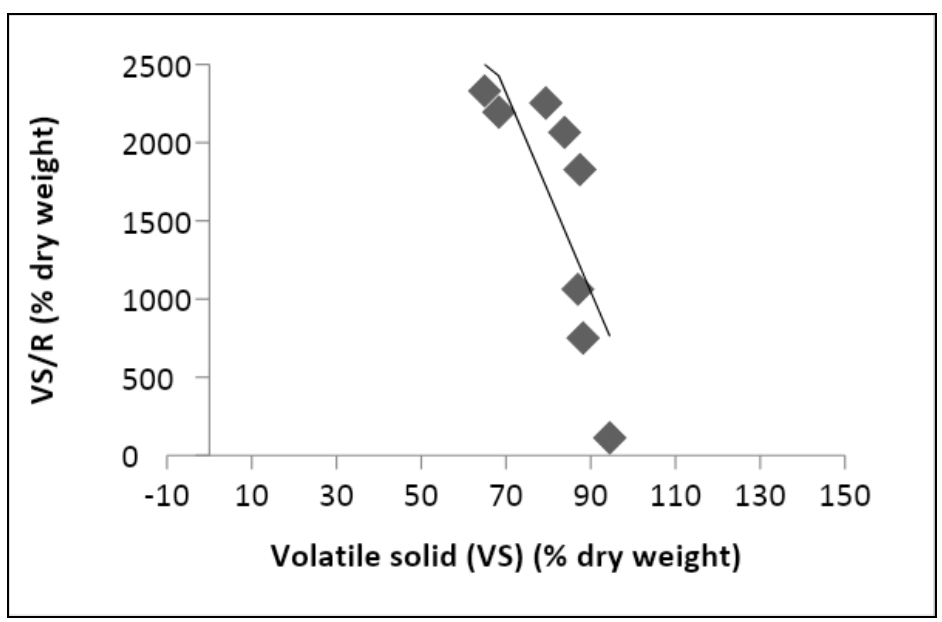

Figure 12. VS/R against VS for Run C

The formula for linear equations obtained from the VS/R graph against VS and the regression factor as shown in Table 4.

Table 4. Linear equation for VS/R graph against VS and regression factor

\begin{tabular}{c|c|c}
\hline Run & Liner equation & Regression factor \\
\hline A & $\mathrm{Y}=-61.042 \mathrm{x}+6216.9$ & 0.6423 \\
B & $\mathrm{Y}=-82.443 \mathrm{x}+8761.3$ & 0.8378 \\
C & $\mathrm{Y}=-63.575 \mathrm{x}+6769.3$ & 0.6195 \\
\hline
\end{tabular}

Based on regression factor value obtained from exponential function and linear function, it is found that Run B composting process is best in terms of volatile solids degradation process (VS). Therefore, linear function for Run B has been selected as kinetic mode for Phase composting process. The intercept and slope values obtained from the above linear equations are then considered for $K_{1}$ and $K_{2}$ values. The value of 
$\mathrm{K}_{2}$ is calculated by inverting the value of the slope. Whereas the value of $\mathrm{K}_{1}$ is obtained by multiplying the value of $\mathrm{K}_{2}$ with the intercept value from the linear equation above. The conclusions on the values of slope, intercept, $\mathrm{K}_{1}$ and $\mathrm{K}_{2}$ are shown in Table 5.

Table 5. Slope, intercept and $K_{1}$ and $K_{2}$ value

\begin{tabular}{c|c|c|c|c}
\hline Run & Slope & Intercept & $\mathbf{K}_{\mathbf{1}}$ & $\mathbf{K}_{\mathbf{2}}$ \\
\hline A & 61.042 & 6216.9 & 101.9572 & 0.0164 \\
B & 82.443 & 8761.3 & 106.0117 & 0.0121 \\
C & 63.575 & 6769.3 & 106.2780 & 0.0157 \\
Mean & & & 103.7517 & 0.0142 \\
\hline
\end{tabular}

From Table 5, the value of $\mathrm{K}_{1}$ obtained is within the range 101.957-106.2780, whereas the value of $K_{2}$ is in the range of $0.0121-0.0164$. The mean values of $K_{1}$ and $\mathrm{K}_{2}$ are 103.7517 and 0.0142 respectively. Then, the percent of error of each constant obtained is also calculated. The result of the percent of error and standard deviation as shown in Table 6.

Table 6. The percent of error, mean and standard deviation of $K_{1}$ and $K_{2}$ on each run

\begin{tabular}{c|c|c|c|c}
\hline $\begin{array}{c}\text { Run/mean/standard } \\
\text { deviation }\end{array}$ & $\mathbf{K}_{\mathbf{2}}$ & Percent of error $\mathbf{K}_{\mathbf{2}} \mathbf{( \% )}$ & $\mathbf{K}_{\mathbf{1}}$ & Percent of error $\mathbf{K}_{\mathbf{1}} \mathbf{( \% )}$ \\
\hline A & 0.0164 & 15.49 & 101.957 & 1.73 \\
B & 0.0121 & 14.79 & 106.0117 & 2.18 \\
C & 0.0157 & 10.56 & 106.2780 & 2.43 \\
Mean & 0.0142 & 13.0275 & 103.7517 & 2.305 \\
Standard deviation & 0.00216 & 2.4730 & 2.8084 & 0.4805 \\
\hline
\end{tabular}

From the results obtained in Table 6, it is found that the percent of error for the $\mathrm{K}_{2}$ constant is within the range of $10.56-15.49 \%$ with a mean value of $13.0275 \%$. Whereas, the maximum percent of error for the $\mathrm{K}_{1}$ constant is $2.43 \%$ and the minimum value is $1.73 \%$ with a mean value of $2.305 \%$. If compared to the mean values of $\mathrm{K}_{1}$ and $\mathrm{K}_{2}$ each recorded at $2.305 \%$ and $13.0275 \%$ respectively, it is found that the $\mathrm{K}_{2}$ constant value is higher than $K_{1}$ and this indicates that the value of $K_{2}$ is a variable independent. This is consistent with the Michaelis Menten model, while the $\mathrm{K}_{1}$ value is dissociation constant for a system. Meanwhile, $\mathrm{K}_{2}$ is the variable dependent on composting system towards the microbial population found in the compost material.

The constants obtained from this experiment are also compared with previous earlier study by Whang and Meenaghan (1980), Seng (1999) and Tweib et al. (2014). $\mathrm{K}_{1}$ and $\mathrm{K}_{2}$ value obtained from Whang and Meenaghan (1980) study are 1.2243 and 0.0325 , resepectively. The value of $K_{1}$ and $K_{2}$ from Seng (1999) study are 80.515 and 0.9029 , respectively. Meanwhile $\mathrm{K}_{1}$ and $\mathrm{K}_{2}$ value from Tweib et al. (2014) are 81.64 and 1.0301, respectively. The value of $\mathrm{K}_{1}$ and $\mathrm{K}_{2}$ from this study shows a big difference compared to the value obtained from Whang and Meenaghan (1980). This difference is due to the different experiments performed. Whang and Meenaghan (1980) have used carbon fraction as a limitation indicator by using a unit of weight of carbon (gram) per weight of ash (gram) which finally the result found is dimensionless $(\mathrm{g} / \mathrm{g})$. While this study uses volatile material (VS) as an indicator parameter, expressed as a percentage unit $(\%)$ per dry weight sample. However, the similarities between this study and the 
studies conducted by Seng (1999) and Tweib et al. (2014) are using volatile material (VS) as indicator parameters, which are expressed in percentages (\%) per dry weight sample. In addition, the $\mathrm{K}_{1}$ constant value is equal to the initial value of the indicator parameter which is the percentage of volatile material. Thus, the magnitude of $K_{1}$ values in the results of this study and the study conducted by Seng (1999) and Tweib et al. (2014) is in two digits (in percent value), while the results of the study by Whang and Meenaghan (1980) are in the form of one digit.

The value of $\mathrm{K}_{2}$ is the system variable as defined in the Michaelis-Menten Model, where this value depends on the number of microbial populations and the second stage constant reaction, $\mathrm{k}_{2}$. Due to the function of the relationship between the total microbial population and the operating system, the $\mathrm{K}_{2}$ value indirectly serves as an indicator of the efficiency of a composting system. Found that $\mathrm{K}_{2}$ constant value for this study and the research done by Whang and Meenaghan (1980) is almost identical. Whang and Meenaghan (1980) have used a mixture of cow and wood dust as a compost material while this study uses EFB and POME as compost materials and carried out on a large scale. Whereas, studies conducted by Seng (1999) and Tweib et al. (1999) were conducted on a small scale, hence the value of $\mathrm{K}_{2}$ in both studies was greater compared to this study and Whang and Meenaghan (1980) because the composting process on the laboratory scale was easier to control than the large-scale composting/pilot scale

Based on the results of the 3 Runs that have been done, it is found that the kinetic change in this study has the best mathematical expression is in Run B as Equations 17 and 18 below:

$$
y=103.31^{-0.015 x} \quad r^{2}=0.9097
$$

where $\mathrm{y}=$ Volatile solid material, $\mathrm{x}=$ time.

After Equation 17 above is obtained, plot VS/R against VS for model is also done to get linear equations:

$$
y=-82.443 x+8761.3 \quad r^{2}=0.8378
$$

The $K_{1}$ value for Run B is 106.0117 and $K_{2}$ is 0.012 . From the volatile kinetic results obtained from this study, two assumptions can be made i.e., the formation of simple complex mixtures and endogenous reactions are irreversible.

\section{Conclusion}

The production of sludge and solid materials in the palm oil plant, as well as the need to address the increasingly expensive disposal problems as well as the current disposal methods that potentially create contaminants and their own sludge potential as soil adapters are the contributing factors and the stimulants in the production and use of composting methods. In the composting process, optimization is an important step in obtaining an effective process and good compost quality. On average, $150 \mathrm{~kg}$ of EFB fibers have been used in each Runs in this experimental study. The maximum temperature (thermophilic temperature) achieved at Run $\mathrm{A}, \mathrm{B}, \mathrm{C}$ is $55^{\circ} \mathrm{C}, 43^{\circ} \mathrm{C}$ and $53.3^{\circ} \mathrm{C}$, respectively. For the final $\mathrm{C} / \mathrm{N}$ ratios of Run $\mathrm{A}, \mathrm{B}$ and $\mathrm{C}$ respectively are 20.61 , 13.06 and 14.51 respectively. Based on the $\mathrm{C} / \mathrm{N}$ final value reading at each run, it can be 
concluded that all runs achieve the optimum $\mathrm{C} / \mathrm{N}$ ratio. However, the lowest $\mathrm{C} / \mathrm{N}$ ratio is obtained in Run B. This is compounded by the mixture in Run B using more recycle compost as well as assisting in the process of decomposition of fresh compost. Recycle compost used in this study contains a low $\mathrm{C} / \mathrm{N}$ ratio of 10.3 and has matured over 1 year. In kinetic studies, volatile changes in Run B experiments are also seen to be more stable. In the determination of volatile solid kinetic for the composting process, it was found that the Michaelis Menten model was appropriate. Overall, it can be concluded that the composting process is one of the alternatives to solving the problem of solid waste dumping in palm oil plantation in an integrated solid waste management system. This method has the potential to conserve and retrieve beneficial ingredients compost with many positive features. The resulting compost is also the final product that can be used as a soil enhancer or plant fertilizer.

\section{REFERENCES}

[1] Bernal, M. P., Paredes, C., Sanchez-Monedero, M. A., Roig, A. (1998): Carbon mineralization from organik waste at different composting stages during their incubation with soil. - Agr. Ecosyst. Environ. 69: 175-189.

[2] Bustamante, M. A., Paredes, C., Marhuenda-Egea, F. C., Pérez-Espinosa, A., Bernal, M. P., Moral, R. (2008): Co-composting of distillery wastes with animal manures: Carbon and nitrogen transformations in the evaluation of compost stability. - Chemosphere 72 : 551-557.

[3] Ge, J., Huang, G., Huang, J., Zeng, J., Han, L. (2015): Mechanism and kinetics of organic matter degradation based on particle structure variation during pig manure aerobic composting. - Journal of Hazardous Materials 292: 19-26.

[4] Gilmour, J. T., Clark, M. D., Mark, D., Daniel, S. M. (1996): Predicting long-term decomposition of biosolids with a seven-day test. - Journal of Environmental Quality 25(4): 766-770.

[5] Giwa, A. S., Heng Xu, H., Wu, J., Li, Y., Chang, F., Zhang, X., Jin, Z., Huang, B., Wang, K. (2018): Sustainable recycling of residues from the food waste (FW) composting plant via pyrolysis: thermal characterization and kinetic studies. - Journal of Cleaner Production 180: 43-49.

[6] Hoyos, S. E. G., Juarez, J. V., Ramonet, C. A., Lopez, J. G., Rios, A. A., Uribe, E. G. (2002): Aerobic thermophilic composting of waste sludge from gelatin-grenetine industry. - Resourcers Conservation and Recycling 34: 161-173.

[7] Kulikowska, D. (2016): Kinetics of organic matter removal and humification progress during sewage sludge composting. - Waste Management 49: 196-203.

[8] Levenspiel, O. (1999): Chemical Reaction Engineering (3rd Ed.). - John Wiley, New York.

[9] Manu, M. K., Kumar, R., Garg, A. (2016): Drum composting of food waste: a kinetic study. - Procedia Environmental Sciences 35: 456-463.

[10] Mason, I. G. (2009): Predicting biodegradable volatile solids degradation profiles in the composting process. - Waste Management 29: 559-569.

[11] Peláez, C., Mejia, A., Planas, A. (2004): Development of a solid phase kinetic assay for determination of enzyme activities during composting. - Process Biochemistry 39: 971975.

[12] Petric, I., Helic, A., Avdic, E. A. (2012): Evolution of process parameters and determination of kinetics for co-composting of organic fraction of municipal solid waste with poultry manure. - Bioresource Technology 117: 107-116.

[13] Planas, A. Pelaez, C. A. (2001): Composting of cattle and agriculture waste: variables and processes. - Afinidad 58: 93-104. 
[14] Pressel, F., Bidlingmaier, W. (1981): Analyzing decay rate of composting. - Biocycle 22(5): 50-51.

[15] Seng, N. H. (1999): Kinetic study of laboratory scale composting process. - Tesis M. Eng, Universiti Putra Malaysia, Selangor, pp. 1-88.

[16] Stloukal, P., Pekarová, S., Kalendova, A., Mattausch, H., Laske, S., Holzer, C., Chitu, L., Bodner, S., Maier, G., Slouf, M., Koutny, M. (2015): Kinetics and mechanism of the biodegradation of PLA/clay nanocomposites during thermophilic phase of composting process. - Waste Management 42: 31-40.

[17] Tiquia, S. M., Tam, N. F. Y., Hodgkis, I. J. (1996): Microbial activities during composting of spent manure sawdust litter at different moisture content. - Bioresource Technology 55: 201-205.

[18] Tweib, S. A., Abd Rahman, R., Khalil, M. S. (2014): Determination of kinetics of co composting of organic fraction of municipal solid waste with palm oil mill sludge (POMS). - Journal of Solid Waste Technology and Management 40 (2): 136-147.

[19] Vikman, M., S. Karjomaa, S., Kapanen, A., Wallenius, K., Itävaara, M. (2002): The influence of lignin content and temperature on the biodegradation of lignocellulose in composting conditions. - Appl Microbiol Biotechnol. 59: 591-598.

[20] Whang, D. S., Meenaghan, G. F. (1980): Kinetic model of composting process. Compost Sci./Land Utiliz. 21: 44-46.

[21] Yamada, Y., Kawase, Y. (2006): Aerobic composting of waste activated sludge: kinetic analysis for microbiological reaction and oxygen consumption. - Waste Management 26: 49-61.

[22] Zhang, J., Gao, D., Chen, T. B., Zheng, G. D., Jun Chen, J., Maa, C., Guo, S. L., Du, W. (2010): Simulation of substrate degradation in composting of sewage sludge. - Waste Management 30: 1931-1938. 